\title{
DURABILITY OF SOLE LEATHER FILLED WITH SULPHITE CELLULOSE EXTRACT
}

\author{
By Roy C. Bowker
}

ABSTRACT

Four lots of leather were prepared and tested to determine the comparative durability of sole leather filled respectively with sulphite cellulose extract and with the ordinary tanning materials such as chestnut wood extract and quebracho extract. Physical data obtained as to the actual service tests and chemical analyses of both the new and worn soles failed to disclose a quality difference between the two leathers.

\section{INTRODUCTION}

The importance of utilizing the wood substance contained in the waste sulphite liquor, which at one time was discharged from the pulp mills as useless waste, is evidenced by the large amount of research which has been conducted on the subject in every wood-pulp-producing country.

One of the principal methods proposed for utilizing these waste liquors is the production of sulphite cellulose extract for use in making leather. This use of the material has been discussed with considerable interest, resulting in a remarkable diversity of opinion. It has been stated that the extract does not contain tanning properties, and hence is not a "true" tanning material as are such vegetable materials as oak bark, quebracho, and chestnut wood. It is generally considered that the material contains no tannin. However, experiments have shown that a hide treated with certain of the sulphite extracts will absorb as much as 25 per cent of substances which will preserve the hide, which is the essential function of a tanning material.

There are many different methods for treating the waste liquors to produce an extract for use in making leather, and hence there are correspondingly many different products. This may account in some measure for the varied results obtained from their use by investigators. Whether it is proposed to use the material either in tanning or filling, the waste liquor should be treated to remove such substances as iron and lime, which have a detrimental effect on the leather. 
American tanners have not been successful in their attempts to tan hides with sulphite cellulose extract, and it is generally considered as having no place in the tanyard.

It has found, however, a wide application as a filling material in the manufacture of sole leather. After the hides have been thoroughly tanned in the yard they still lack the firmness and weight required. It is the general commercial practice to produce these qualities by filling the leather with tanning materials by drumming, tempering, and dry dipping.

Since the opinion has often been expressed that sole leather filled with this extract was inferior, and since no known data on the subject were in existence, this investigation was made to determine the comparative durability of sole leather filled with sulphite cellulose extract and sole leather filled with the ordinary vegetable tanning materials.

\section{DESCRIPTION OF LEATHER TESTED}

Several tanners were approached regarding the preparation of leather for the tests, and three different establishments were chosen in order that the leather used might be representative. The history of the various lots of leather tested follows:

LоT No. I.-This tannery made two brands of leather commercially, one of which contained sulphite cellulose extract. Five hides were selected for the test. The tannage up to the wringer was a vat tannage of 60 per cent chestnut oak and 40 per cent chestnut. The leather was then filled with chestnut extract by drumming and finished in sulphited quebracho extract. Five alternate bends were then bleached, oiled, dried, and rolled. The five remaining bends were bleached, 'partially oiled, dried, dry dipped in sulphite cellulose extract, redried, oiled, and rolled.

Lот No. 2.-Five hides were carried through the yard whole and then split after the third layer. Five bends were then extracted in drums with the ordinary tanning materials, tempered, bleached, oiled, and rolled. The remaining five bends were drummed in roo per cent sulphite cellulose extract, lightly bleached, oiled, dried, dry dipped in warm sulphite cellulose extract of $5^{\circ}$ Twaddle, oiled, dried, and rolled.

Lor No. 3.-In this tannery the hides were given 5 layers in the yard of 15 days each. No sulphite cellulose extract was used ordinarily in this tannery, but the company was interested in the proposed tests and prepared samples as desired. Four hides were 
carried through the yard and were removed after the fourth layer. Four bends were then extracted in drums with roo per cent sulphite cellulose extract, then tempered 5 days in a 50 barkometer tempering liquor of the same extract, oiled, dried, dry dipped in 70 barkometer liquor made from sulphite cellulose extract, and finished as usual. The remaining four bends were extracted in drums with a mixture of chestnut wood extract and quebracho extract (50 per cent each), then tempered 5 days in a 50 barkometer tempering liquor made up of 50 per cent each of chestnut wood and quebracho extract, oiled, dried, dry dipped in 70 barkometer chestnut wood liquor, and finished as usual.

Lor No. 4. -This leather came from the same tannery as did lot No. 3. Four hides were used and the bends were removed after the fifth and last layer instead of after the fourth layer, as in lot No. 3. The two groups of bends received the same treatment given those in lot No. 3, with the exception of dry dipping, which was omitted.

\section{WEAR TESTS}

After the leather was received at the laboratory full soles were cut and matched for test in a manner similar to that described in Technologic Paper No. 138 , so that the soles of each pair were cut from similar locations on the same hide. One sole of each pair contained sulphite cellulose extract and one contained the ordinary vegetable tanning materials used in the tannery which furnished the leather.

The leather was subjected to actual wearing test on laborers, laboratory workers, and office workers. The conditions of service were not uniform for all the different pairs of soles, some of which were worn on concrete floors, in machine shops, in boiler rooms, or in outside weather conditions.

TABLE 1.-Results of Wear Tests

\begin{tabular}{|c|c|c|c|c|c|c|c|}
\hline \multirow{2}{*}{ Lot No. } & \multirow{2}{*}{$\begin{array}{l}\text { Pairs of } \\
\text { soles } \\
\text { tested }\end{array}$} & \multicolumn{2}{|c|}{$\begin{array}{l}\text { Average iron per } \\
\text { sole }\end{array}$} & \multicolumn{2}{|c|}{ Days wear per sole } & \multicolumn{2}{|c|}{ Days wear per iron } \\
\hline & & $\mathrm{O}^{\mathrm{a}}$ & $\mathrm{Sb}^{\mathrm{b}}$ & 0 & $\mathbf{S}$ & 0 & $\mathbf{S}$ \\
\hline \multirow{2}{*}{ 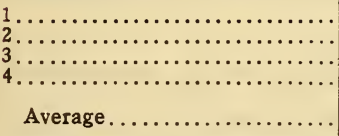 } & $\begin{array}{l}73 \\
90 \\
54 \\
63\end{array}$ & $\begin{array}{l}9.91 \\
9.60 \\
8.69 \\
8.44\end{array}$ & $\begin{array}{l}9.66 \\
9.54 \\
8.51 \\
8.48\end{array}$ & $\begin{array}{r}118.7 \\
94.4 \\
59.6 \\
63.7\end{array}$ & $\begin{array}{r}115.7 \\
90.5 \\
58.1 \\
67.9\end{array}$ & $\begin{array}{r}11.97 \\
9.84 \\
6.86 \\
7.55\end{array}$ & $\begin{array}{r}11.98 \\
9.49 \\
6.83 \\
8.01\end{array}$ \\
\hline & $\ldots \ldots$ & 9.16 & 9.05 & 84.1 & 83.1 & 9.06 & 9.08 \\
\hline
\end{tabular}

¿ $\mathrm{O}=$ Soles filled with ordinary vegetable tanning materials

b $\mathrm{S}=$ Soles filled either entirely or partially with sulphite cellulose extract 


\section{CHEMICAL ANALYSES}

The following tables give the complete analyses for the different leathers both for the new and worn soles:

TABLE 2.-Analyses of New and Worn Soles, Based on 12 Per Cent Moisture

NEW SOLES

\begin{tabular}{|c|c|c|c|c|c|c|c|c|}
\hline \multirow{2}{*}{ Material } & \multicolumn{2}{|c|}{ Lot No. 1} & \multicolumn{2}{|c|}{ Lot No. 2} & \multicolumn{2}{|c|}{ Lot No. 3} & \multicolumn{2}{|c|}{ Lot No. 4} \\
\hline & $\mathrm{O}^{a}$ & $S^{b}$ & 0 & $\mathrm{~S}$ & 0 & $\mathbf{S}$ & 0 & $\mathbf{S}$ \\
\hline 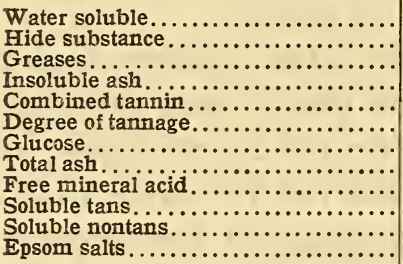 & $\begin{array}{r}25.19 \\
30.53 \\
3.09 \\
.21 \\
28.98 \\
93 \\
3.17 \\
1.54 \\
.23 \\
15.06 \\
10.12 \\
2.35\end{array}$ & $\begin{array}{r}31.69 \\
28.02 \\
3.06 \\
.29 \\
24.94 \\
87 \\
7.86 \\
1.85 \\
.05 \\
19.37 \\
12.27 \\
3.38\end{array}$ & $\begin{array}{r}26.81 \\
33.62 \\
4.49 \\
.17 \\
22.91 \\
66 \\
5.87 \\
2.04 \\
.53 \\
16.34 \\
10.47 \\
1.52\end{array}$ & $\begin{array}{r}28.96 \\
34.11 \\
4.38 \\
.25 \\
20.30 \\
58 \\
6.78 \\
2.22 \\
.95 \\
13.24 \\
15.75 \\
1.96\end{array}$ & $\begin{array}{r}31.53 \\
31.01 \\
4.51 \\
.23 \\
20.72 \\
64 \\
11.02 \\
1.76 \\
.53 \\
13.07 \\
18.49 \\
2.66\end{array}$ & $\begin{array}{r}29.01 \\
34.00 \\
4.61 \\
.29 \\
20.09 \\
57 \\
11.32 \\
1.77 \\
.48 \\
11.63 \\
17.40 \\
2.50\end{array}$ & $\begin{array}{r}24.30 \\
37.42 \\
3.38 \\
.19 \\
22.71 \\
58 \\
4.45 \\
1.26 \\
.14 \\
11.68 \\
12.62 \\
1.93\end{array}$ & $\begin{array}{r}25.25 \\
35.60 \\
4.12 \\
.29 \\
22.74 \\
62 \\
2.48 \\
1.47 \\
.10 \\
15.95 \\
9.30 \\
2.36\end{array}$ \\
\hline
\end{tabular}

Worn Soles

\begin{tabular}{|c|c|c|c|c|c|c|c|c|}
\hline 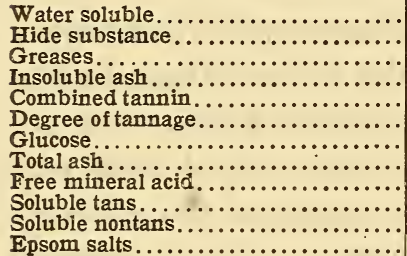 & $\begin{array}{r}17.81 \\
35.62 \\
3.52 \\
2.46 \\
28.59 \\
80 \\
1.00 \\
3.97 \\
.30 \\
9.61 \\
8.20 \\
2.44\end{array}$ & $\begin{array}{r}19.87 \\
31.70 \\
3.90 \\
4.43 \\
28.10 \\
89 \\
2.42 \\
5.70 \\
10.15 \\
10.83 \\
9.04 \\
2.63\end{array}$ & $\begin{array}{r}18.73 \\
34.37 \\
6.04 \\
4.66 \\
24.20 \\
71 \\
2.52 \\
5.82 \\
.59 \\
8.10 \\
10.63 \\
2.25\end{array}$ & $\begin{array}{r}18.67 \\
34.75 \\
5.44 \\
5.24 \\
23.90 \\
69 \\
2.21 \\
7.59 \\
.73 \\
8.24 \\
10.43 \\
1.35\end{array}$ & $\begin{array}{r}20.40 \\
34.75 \\
5.94 \\
3.88 \\
23.03 \\
66 \\
2.90 \\
5.10 \\
.58 \\
10.30 \\
10.10 \\
2.57\end{array}$ & $\begin{array}{r}19.57 \\
36.30 \\
5.51 \\
5.04 \\
21.58 \\
60 \\
2.68 \\
6.86 \\
.44 \\
9.20 \\
10.37 \\
2.15\end{array}$ & $\begin{array}{r}18.44 \\
35.40 \\
6.31 \\
6.49 \\
21.36 \\
60 \\
2.21 \\
7.80 \\
.25 \\
9.06 \\
9.38 \\
1.78\end{array}$ & $\begin{array}{r}17.16 \\
35.55 \\
5.35 \\
5.78 \\
24.16 \\
68 \\
1.93 \\
7.56 \\
.25 \\
9.81 \\
7.35 \\
2.13\end{array}$ \\
\hline
\end{tabular}

${ }^{a} \mathrm{O}=$ Leather filled with ordinary vegetable tanning materials

$\mathrm{b} \mathrm{S}=$ Leather filled entirely or partially with sulphite cellulose extract

The results of the chemical analyses, broadly interpreted, indicate that from the analytical standpoint the quality of the leather was not impaired by filling with sulphite cellulose extract. A greater increase in the degree of tannage after wear for the sulphite-filled leathers than for the leathers filled in the usual manner is shown for each lot. The analyses also indicate that the sulphite cellulose extract is as well fixed in the leather as are the vegetable tanning materials such as chestnut and quebracho, and certainly more fixed than glucose, which was practically all withdrawn from the leather during wear, corrobrating previous data on this subject.

Under ordinary service conditions it would also be expected that most of the Epsom salts would be withdrawn from the leather during wear. In this particular series of tests many of the indi- 
viduals wearing test soles worked with such materials as lime, cement, and magnesite. It is therefore not surprising that the analyses of the worn soles show no appreciable loss in Epsom salts.

In lot No. I, the glucose content of the leather filled with sulphite cellulose extract is considerably more than the glucose present in the leather filled with the ordinary vegetable materials. This can be explained by the fact that the tanner of these leathers uses a greater amount of glucose in filling the former leather than is the custom in filling his regular tannage.

The large difference in glucose content between lots 3 and 4 , which were made by the same tanner, is caused by the fact that lot No. 3 was removed after the fourth layer instead of after the fifth layer, as for lot No. 4. Lot No. 3 was then in a slack tanned condition and would more readily absorb a greater amount of glucose than leather more thoroughly tanned, as was lot No. 4 .

TABLE 3.-Analyses of Sulphite Cellulose Extracts Used

\begin{tabular}{|c|c|c|c|}
\hline Material & $\begin{array}{l}\text { Used in } \\
\text { lot No. } 1\end{array}$ & $\begin{array}{l}\text { Used in } \\
\text { lot No. } 2\end{array}$ & $\begin{array}{l}\text { Used in } \\
\text { lots No. } 3 \\
\text { and } 4\end{array}$ \\
\hline 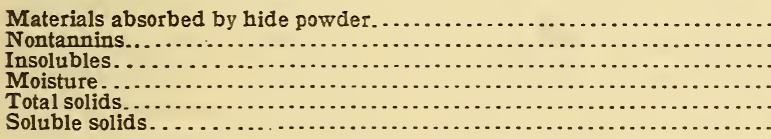 & $\begin{array}{l}30.09 \\
24.71 \\
45.07 \\
54.87 \\
54.80\end{array}$ & $\begin{array}{r}26.56 \\
25.12 \\
.00 \\
48.33 \\
51.68 \\
51.68\end{array}$ & $\begin{array}{l}27.25 \\
24.30 \\
.12 \\
48.33 \\
51.67 \\
51.55\end{array}$ \\
\hline
\end{tabular}

Analysis of lot No. I was made from sample furnished by the tannery. The remaining analyses were furnished by the tanners who furnished the leather to which reference is made by the lot numbers. The tanners of lot Nos. I, 3, and 4 referred to the sulphite cellulose extract used, as "spruce extract." The tanners of lot No. 2 referred to the sulphite cellulose extract used as that manufactured by the Robeson Process Co., New York City.

The tanners who furnished the leathers were C. C. Smoot \& Sons, The American Oak Leather Co., and the Ashland Leather Co.

\section{SUMMARY}

As a result of these tests the following observations can be made regarding the sulphite cellulose extracts used in this investigation as fillers for sole leather:

I. Leather filled either partially or entirely with sulphite cellulose extract is as durable as leather filled with the ordinary tanning materials, such as chestnut and quebracho. 
2. As reflected by the chemical analyses, this extract is equally as firmly fixed in the leather as these vegetable tanning materials.

3. The use of such a material instead of chestnut and quebracho would conserve these materials for use in the actual tanning processes for which they are suitable and for which sulphite cellulose extract has not been successfully used.

4. It is probable that this material could be used as a filler in place of the more soluble glucose, thereby producing a more waterproof leather.

5. Leather filled with this material can be made which will have as light and uniform a color as leather filled with the ordinary materials. This was the case for lots No. I and 2. There was a slight difference in the color in lots No. 3 and 4 , the leather filled with sulphite cellulose extract being a little darker.

6. Using this material as a filler has no more effect on the aging of the leather than the ordinary materials, since samples of these leathers which have been in the laboratory for over two years are still in a satisfactory and pliable condition.

WASHington, April 8, I922. 